\title{
Pengaruh Sistem Tanam Jajar Legowo yang Dimodifikasi dan Jumlah Bibit Terhadap Pertumbuhan dan Produksi Padi Sawah (Oryza sativaL.) di Desa Tanjung Rejo Kecamatan Percut Sei Tuan
}

\author{
Endow Richardo, Erwin Masrul Harahap*, Benny Hidayat \\ Program Studi Agroteknologi, Fakultas Pertanian, USU, Medan 20155 \\ *Corresponding author :ermashar@yahoo.com
}

\begin{abstract}
ABSTRAK
Peningkatan produksi padi di Indonesia dipengaruhi beberapa faktor, salah satu yaitu penggunaan jumlah bibit serta pengoptimalan populasi tanaman melalui jarak tanam padi. Penelitian bertujuan untuk mempelajari pengaruh sistem tanam jajar legowo yang dimodifikasi dan jumlah bibit. Penelitian ini dilaksanakan di lahan sawah Desa Tanjung Rejo Kecamatan Percut Sei Tuan Kabupaten Deli Serdang dan dimulai pada bulan Mei sampai dengan September 2017. Penelitian ini menggunakan Rancangan Acak Lengkap 2 Faktor, yaitu jumlah bibit ( 1 bibit, 2 bibit, 3 bibit ) dan Populasi tanaman berdasarkan sistem tanam jajar legowo yang dimodifikasi ( sistem tanam jarak konvensional dengan populasi 48 rumpun per petak, sistem tanam jajar legowo dengan populasi 60 rumpun per petak, sistem tanam jajar legowo dengan populasi 114 rumpun per petak, sistem tanam jajar legowo dengan populasi 154 rumpun per petak, sistem tanam jajar legowo dengan populasi 190 rumpun per petak). Hasil penelitian menunjukkan bahwa penggunaan 2 bibit per rumpun dan sistem tanam jajar legowo dengan populasi 60 rumpun per petak berpengaruh secara nyata dalam meningkatkan produksi padi sawah (Oryza sativa L.). Interaksi antara faktor jumlah bibit dan populasi tanaman tidak meningkatkan pertumbuhan tetapi berpengaruh nyata meningkatkan produksi padi sawah (Oryza sativa L.).
\end{abstract}

Kata Kunci :jajar legowo, jumlah bibit, padi sawah

\section{PENDAHULUAN}

Pertambahan penduduk yang tinggi di Indonesia mempengaruhi kebutuhan, terutama kebutuhan pangan. Berdasarkan hasil SUSENAS BPS, rata-rata konsumsi per kapita bahan makanan yang mengandung beras per tahun mencapai 97,426 kg/tahun dengan laju pertumbuhan $\quad 1,49 \% \quad$ dan penduduk yang telah mencapai 237,46 juta jiwa. Sumatera Utara merupakan penghasil padi keenam terbesar dengan produksi padi pada tahun 2015 mencapai 4,04 juta ton dengan produktivitas padi 51,74 kuintal/hektar dan luas panen 0,78 juta hektar. Hal ini menunjukkan bahwa produktivitas padi di Sumatera Utara perlu ditingkatkan untuk memenuhi kebutuhan pangan di Indonesia.
Penggunaan jumlah bibit yang sesuai merupakan salah satu faktor untuk memperbaiki produktivitas tanaman padi. Penggunaan bibit per lubang tanam yang tepat dapat mengurangi persaingan antar tanaman dalam satu rumpun maupun antar rumpun. Para petani dalam membudidayakan tanaman padi sawah kurang memperhatikan jumlah bibit yang ditanam pada setiap lubang tanam, dimana petani menggunakan jumlah bibit yang banyak dengan tujuan meningkatkan produksi tanaman. Hal ini akan meningkatkan kompetisi kebutuhan akan unsur hara dan adanya perubahan iklim mikro diantara bibit tanaman tersebut (Ali dkk., 2017).

Melalui pemilihan jarak tanam yang tepat maka tingkat persaingan antar maupun intern tanaman dapat ditekan serendah mungkin. Pada saat ini jarak tanam yang dianjurkan berupa sistem tanam jajar legowo, 
dimana menggunakan pola tanam berselang seling antar dua atau lebih (biasanya dua atau empat) baris tanaman padi dan satu baris kosong. Sistem tanam ini memberi kemudahan dalam pengelolaan serta meningkatkan jumlah bibit per luas tanam dan produktivitas padi meningkat $10-15 \%$ (Sembiring, 2001).

Dengan uraian yang telah ada, penulis melakukan penelitian untuk mengetahui pengaruh jumlah bibit dan sistem tanam jajar legowo tehadap pertumbuhan dan produksi padi sawah. Dengan harapan hasil penelitian dapat menjadi informasi bagi petani dalam budidaya tanaman padi sawah.

\section{BAHAN DAN METODE}

Penelitian ini dilaksanakan di Desa Tanjung Rejo, Kecamatan Percut Sei Tuan dengan ketinggian tempat +20 meter di atas permukaan laut. Penelitian ini dilaksanakan dari bulan Mei 2017 sampai dengan September 2017.

Bahan yang digunakan pada penelitian ini adalah benih padi dari varietas Ciherang, cup air mineral, lahan sawah Desa Tanjung Rejo Kecamatan Percut Sei Tuan, pupuk dasar yang digunakan adalah pupuk organik, urea, SP-36, KCl, dolomit, ZA, dan pestisida.

Alat yang digunakan pada penelitian ini yaitu ; traktor, tali plastik, meteran,, timbangan analitik, spidol/pensil, kamera, dan sejumlah alat-alat pendukung.

Penelitian ini menggunakan Rancangan Acak Lengkap Faktorial dengan 3 ulangan. Faktor I : jumlah bibit (B), terdiri atas 3 taraf $\mathrm{B}_{1}=1$ bibit per lubang tanam, $\mathrm{B}_{2}=2$ bibit per lubang tanam, $\mathrm{B}_{3}: 3$ bibit per lubang tanam. Faktor II : populasi tanaman berdasarkan sistem tanam jajar legowo yang dimodifikasi (L) terdiri atas 5 taraf $: \mathrm{L}_{0}=$ sistem tanam petani (tegel) dengan populasi 48 rumpun/petak, $\mathrm{L}_{1}=$ jajar legowo dengan populasi $60 \mathrm{rumpun} /$ petak, $\mathrm{L}_{2}=$ jajar legowo dengan populasi 114 rumpun/petak, $\mathrm{L}_{3}=$ jajar legowo dengan populasi 154 rumpun/petak), $\mathrm{L}_{4}=$ jajar legowo dengan populasi 190 rumpun/petak.

\section{HASIL DAN PEMBAHASAN}

\section{Tinggi Tanaman $(\mathbf{c m})$}

Hasil uji beda rataan taraf $5 \%$ pada Tabel 1, dapat dilihat bahwa pada faktor jumlah populasi tanaman berpengaruh nyata terhadap tinggi tanaman. Rataan tinggi tanaman tertinggi terdapat pada perlakuan B2, sedangkan rataan tinggi tanaman terendah terdapat pada perlakuan B1. Hal ini menunjukkan penggunaan jumlah 2 bibit optimal dalam pertumbuhan tinggi tanaman karena proses pertumbuhan seperti fotosintesis berjalan dengan optimal. Menurut literatur Marlina dkk., (2017), bahwa laju fotosintesis dibatasi oleh ketersediaan $\mathrm{CO}^{2}$ disekitar daun.Jika dalam satu rumpun jumlahtanaman lebih banyak maka posisi daun akan berhimpitan dan mengakibatkan terjadinya persaingan penggunaan $\mathrm{CO}^{2}$ di daerah sekitar daun.

Pada faktor jumlah populasi menunjukkan pada umur pengamatan 4 MST perlakuan L4 berbeda nyata dengan perlakuan lainnya, dan pada umur pengamatan 6 MST perlakuan L4 dan L3 berbeda nyata dengan perlakuan L2, L1, dan L0. Peningkatan jumlah populasi tanaman padi berkorelasi positif terhadap tinggi tanaman, karena adanya persaingan dalam mendapatkan serapan sinar matahari . Hal ini sesuai literatur Aribawa (2012), bahwa dengan populasi tanaman yang padat dalam satu hamparan, maka akan memicu terjadinya kompetisi antar tanaman dalam hal pemanfaatan sinar matahari sehingga memacu tanaman lebih tinggi bila dibandingkan dengan populasi tanaman yang lebih rendah, karena adanya perbedaan sistem tanam.

Dapat dilihat bahwa pada pertengahan umur tanaman, tinggi tanaman sudah hampir mencapai rataan maksimal tinggi tanaman. Hal ini dapat disebabkan oleh karena varietas tanaman dan kebutuhan hara yang diterima tanaman terpenuhi dengan adanya penggunaan pupuk yang berimbang. Hal ini sesuai literatur Damanik dkk., (2011), yang menyatakan bahwa pertumbuhan tanaman dipengaruhi oleh dua faktor penting yaitu faktor genetis dan dan faktor lingkungan. 
Tabel 1.Pengaruh Jumlah Populasi Tanaman dan Jumlah Bibit terhadap Tinggi Tanaman $(\mathrm{Cm})$ pada Setiap Umur Pengamatan

\begin{tabular}{|c|c|c|c|c|c|c|c|}
\hline \multirow{2}{*}{$\begin{array}{l}\text { Umur } \\
\text { Pengamatan }\end{array}$} & \multirow{2}{*}{$\begin{array}{l}\text { Jumlah } \\
\text { Bibit }\end{array}$} & \multicolumn{4}{|c|}{ Populasi Tanaman } & \multirow[b]{2}{*}{$\mathrm{L} 4$} & \multirow[b]{2}{*}{ Rataan } \\
\hline & & L0 & L1 & L2 & L3 & & \\
\hline \multirow{5}{*}{$2 \mathrm{MST}$} & & & & Cm---- & 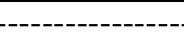 & - & \\
\hline & B1 & 43,45 & 39,64 & 48,11 & 44,96 & 54,39 & $44,04 \mathbf{b A}$ \\
\hline & B2 & 52,33 & 48,05 & 53,27 & 50,57 & 52,31 & $51,05 \mathbf{a A}$ \\
\hline & B3 & 44,94 & 46,38 & 45,81 & 44,59 & 50,79 & \multirow[t]{2}{*}{$45,43 \mathbf{b A}$} \\
\hline & Rataan & 46,90 & 44,69 & 49,06 & 46,70 & 52,49 & \\
\hline \multirow{4}{*}{$4 \mathrm{MST}$} & B1 & 58,25 & 58,2 & 62,46 & 64,37 & 84,89 & $65,63 \mathbf{b B}$ \\
\hline & B2 & 75,79 & 68,56 & 83,41 & 76,27 & 81,77 & \multirow{3}{*}{$\begin{array}{l}77,16 \mathbf{a A} \\
66,08 \mathbf{a b A B}\end{array}$} \\
\hline & B3 & 62,69 & 66,46 & 66,31 & 68,85 & 83,88 & \\
\hline & Rataan & $65,58 \mathbf{b B}$ & $64,40 \mathbf{b B}$ & $70,72 \mathbf{b A B}$ & $69,83 \mathbf{b A B}$ & $83,51 \mathbf{a A}$ & \\
\hline \multirow{4}{*}{$6 \mathrm{MST}$} & B1 & 88,39 & 83,48 & 87,6 & 94,2 & 98,55 & \multirow{4}{*}{$\begin{array}{l}88,41 \\
96,30 \\
91,35\end{array}$} \\
\hline & B2 & 96,37 & 91,99 & 98,62 & 98,23 & 97,49 & \\
\hline & B3 & 88,54 & 93,97 & 90,45 & 92,45 & 102,73 & \\
\hline & Rataan & $91,1 \mathbf{b A B}$ & $89,81 \mathbf{b B}$ & $92,22 \mathbf{b A B}$ & $94,96 \mathbf{a b A B}$ & $99,59 \mathbf{a A}$ & \\
\hline
\end{tabular}

Keterangan: $\quad$ Angka yang diikuti oleh huruf yang berbeda pada kolom yang sama adalah berbeda nyata berdasarkan Uji Jarak Berganda Duncan pada taraf $5 \%$

Jumlah Anakan per lubang tanam (batang)

Pada Tabel 2 dapat dilihat bahwa faktor jumlah populasi hanya berpengaruh nyata terhadap jumlah anakan pada umur pengamatan 6 MST, hasil tertinggi terdapat pada perlakuan L1 dan hasil terendah terdapat pada perlakuan L4. Hal ini menunjukkan bahwa jumlah populasi tanaman yang tinggi menghasilkan jumlah anakan per rumpun yang rendah tetapi meningkatkan tinggi tanaman, berbeda bila dibandingkan dengan jumlah populasi tanaman sedikit. Ini berkaitan dengan jumlah populasi tanaman yang sedikit menyebabkan ruang tumbuh lebih lebar sehingga kompetisi antar tanaman lebih berkurang dan pembentukan anakan lebih baik. Hal ini sesuai literatur Sumardi (2010), menyatakan bahwa penanaman dengan jarak tanam rapat mengakibatkan ruang tumbuh yang terbatas dan mengurangi produksi anakan, baik anakan total maupun anakan produktif.

Pada Tabel 2 dapat dilihat bahwa faktor jumlah bibit berpengaruh nyata pada umur pengamatan 2 MST, hasil rataan tertinggi terdapat pada perlakuan B2 dan rataan terendah terdapat pada perlakuan B1. Pada perlakuan jumlah 1 bibit dan jumlah 3 bibit memiliki pengaruh yang tidak berbeda nyata, dan pada perlakuan jumlah 2 bibit pertumbuhan jumlah anakan lebih tinggi dibandingkan perlakuan lainnya. Hal ini menunjukkan jumlah 2 bibit optimal mengurangi persaingan pada tanaman sehingga lebih mendorong pertumbuhan seperti memperbanyak jumlah anakan. Hal ini sesuai literatur Wangiana dkk.,(2009), bahwa jumlah bibit per lubang tanam mampu memberikan pengaruh yang signifikan (berbeda nyata) terhadap pertumbuhan jumlah daun dan jumlah anakan per rumpun pada tanaman padi.

Pada hasil penelitian diketahui bahwa faktor jumlah bibit berpengaruh nyata pada awal masa pertumbuhan vegetatif, sedangkan faktor jumlah populasi berpengaruh nyata pada pertengahan masa pertumbuhan. Menurut literatur Makarim dan Suhartatik (2009), hal ini disebabkan karena pada awal masa pertumbuhan terjadi persaingan dan adaptasi dalam satu rumpun/lubang. Pertumbuhan yang terjadi berupa ; pertambahan daun, pembentukan anakan, serta munculnya akar sekunder, sedangkan pada pertengahan masa pertumbuhan sudah terjadi persaingan antar rumpun/baris dalam proses pertumbuhan pada pertambahan anakan dan pemanjangan batang hingga pembentukan malai. 
Tabel 2. Pengaruh Jumlah Bibit dan Populasi Tanaman terhadap Jumlah Anakan (batang) pada Setiap Umur Pengamatan

\begin{tabular}{|c|c|c|c|c|c|c|c|}
\hline \multirow{2}{*}{$\begin{array}{c}\text { Umur } \\
\text { Pengamatan } \\
\end{array}$} & \multirow{2}{*}{$\begin{array}{l}\text { Jumlah } \\
\text { Bibit }\end{array}$} & \multicolumn{4}{|c|}{ Populasi Tanaman } & \multirow[b]{2}{*}{$\mathrm{L} 4$} & \multirow[b]{2}{*}{ Rataan } \\
\hline & & L0 & L1 & L2 & L3 & & \\
\hline \multirow{5}{*}{$2 \mathrm{MST}$} & & & & ang-------- & ---------- & & \\
\hline & B1 & 1,87 & 2,93 & 2,93 & 2,33 & 6,60 & $3,33 \mathbf{b A}$ \\
\hline & $\mathrm{B} 2$ & 5,67 & 4,60 & 7,47 & 5,93 & 5,73 & $5,88 \mathbf{a A}$ \\
\hline & B3 & 2,87 & 3,40 & 2,33 & 2,47 & 7,20 & $3,65 \mathbf{b A}$ \\
\hline & Rataan & 3,47 & 3,64 & 4,24 & 3,58 & 6,51 & \\
\hline \multirow{4}{*}{$4 \mathrm{MST}$} & B1 & 14,87 & 15,87 & 13,80 & 12,13 & 13,33 & 14,00 \\
\hline & B2 & 25,73 & 31,13 & 18,60 & 14,93 & 12,27 & 20,53 \\
\hline & B3 & 16,13 & 21,33 & 17,93 & 15,00 & 17,07 & 17,49 \\
\hline & Rataan & 18,91 & 22,78 & 16,78 & 14,02 & 14,22 & \\
\hline \multirow{4}{*}{$6 \mathrm{MST}$} & B1 & 24,87 & 20,53 & 22,33 & 18,67 & 12,33 & 19,75 \\
\hline & B2 & 25,20 & 32,47 & 17,20 & 15,47 & 13,47 & 20,76 \\
\hline & B3 & 30,33 & 29,07 & 19,67 & 14,07 & 14,73 & 21,57 \\
\hline & Rataan & $26,80 \mathbf{a A}$ & $27,36 \mathbf{a A}$ & $19,73 \mathbf{b B}$ & $16,07 \mathbf{b c B}$ & $13,51 \mathbf{c B}$ & \\
\hline
\end{tabular}

Keterangan: Angka yang diikuti oleh huruf yang berbeda pada kolom yang sama adalah berbeda nyata berdasarkan Uji Jarak Berganda Duncan pada taraf 5\% (huruf kecil) dan 1\% (huruf besar)

Jumlah Malai (malai), Panjang Malai (cm), Bobot Gabah 1000 Butir (g), Bobot Jerami Kering (g)

Pada faktor jumlah populasi berpengaruh nyata terhadap parameter jumlah malai. Rataan jumlah malai tertinggi terdapat pada perlakuan L0. Hal ini menunjukkan bahwa jumlah populasi yang tinggi berkaitan dengan adanya persaingan antar rumpun yang tinggi sehingga tanaman lebih sedikit jumlah malai. Hal ini sesuai literatur Simangunsong dkk., (2018), yang menyatakan bahwa jarak tanam yang rapat akan menghasilkan jumlah malai yang sedikit karena persaingan radiasi surya dan unsur hara yang cukup tinggi.

Pada faktor jumlah populasi tanaman dan jumlah bibit tidak memiliki pengaruh yang nyata terhadap panjang malai. Pada setiap perlakuan, dipengaruhi oleh faktor genetik suatu varietas, lingkungan pertanaman serta jumlah malai. Menurut literatur Makarim dan Suhartatik (2009), menyatakan bahwa semakin banyak jumlah malai per $\mathrm{m}^{2}$ dengan cara meningkatkan populasi tanaman, maka semakin pendek malai yang dihasilkan.
Pada parameter bobot 1000 butir gabah kering giling berpengaruh tidak nyata terhadap faktor jumlah populasi tanaman dan jumlah bibit. Tetapi secara perhitungan perlakuan dengan jumlah populasi dan jumlah bibit yang sedikit memiliki rataan yang tinggi karena proses fotosintesis berlangsung optimal. Hal ini sesuai literatur Nararya dkk., (2017), yang menyatakan bahwa proses fotosintesis berlangsung optimal karena memiliki jarak tanam yang lebih lebar, sehingga akumulasi dari asimilat yang dihasilkan dan dialokasikan untuk pengisian biji juga lebih banyak dan berdampak pada bobot dari biji lebih berat serta persentase gabah hampa cenderung lebih sedikit.

Pada parameter bobot jerami kering tidak berpengaruh nyata terhadap faktor jumlah populasi dan jumlah bibit. Hal ini menunjukkan bahwa hasil jerami padi sawah dipengaruhi oleh adanya sifat varietas. Menurut literatur Simangunsong dkk., (2018), menyatakan bahwa bobot jerami akibat dari faktor genetik. 
Tabel 3. Pengaruh Jumlah Bibit dan Populasi Tanaman terhadap Jumlah Malai (malai), Panjang Malai (cm), Bobot Gabah 1000 Butir Gabah Kering Giling (g), Bobot Jerami Kering (g)

\begin{tabular}{|c|c|c|c|c|}
\hline & \multicolumn{3}{|c|}{ Parameter } & \multirow[b]{2}{*}{$\begin{array}{l}\text { Bobot Jerami } \\
\text { Kering (g) }\end{array}$} \\
\hline & $\begin{array}{c}\text { Jumlah Malai } \\
\text { (malai) }\end{array}$ & $\begin{array}{c}\text { Panjang Malai } \\
(\mathrm{cm})\end{array}$ & $\begin{array}{c}\text { Bobot Gabah } \\
1000 \text { Butir GKG } \\
(\mathrm{g})\end{array}$ & \\
\hline \multicolumn{5}{|c|}{ Jumlah Bibit (B) } \\
\hline $\mathrm{B}_{1}$ & 17,47 & 24,43 & 46,01 & 6.898 \\
\hline $\mathrm{B}_{2}$ & 18,19 & 24,89 & 45,59 & 6.730 \\
\hline $\mathrm{B}_{3}$ & 16,8 & 25,03 & 43,25 & 6.108 \\
\hline \multicolumn{5}{|c|}{ Legowo (L) } \\
\hline $\mathrm{L}_{0}$ & $21,64 \mathbf{a A}$ & 25,81 & 45,24 & $8.121 \mathrm{aA}$ \\
\hline $\mathrm{L}_{1}$ & $19,44 \mathbf{a b A B}$ & 25,44 & 48,64 & $7.058 \mathrm{bB}$ \\
\hline $\mathrm{L}_{2}$ & 16,78 bBC & 24,37 & 44,79 & $7.195 b B$ \\
\hline $\mathrm{L}_{3}$ & $17,31 \mathbf{b A B}$ & 23,76 & 45,82 & $5.631 \mathrm{cC}$ \\
\hline $\mathrm{L}_{4}$ & $12,24 \mathbf{c C}$ & 24,52 & 41,03 & $4.890 \mathrm{dD}$ \\
\hline
\end{tabular}

Keterangan : $\quad$ Angka yang diikuti oleh huruf yang berbeda pada kolom yang sama adalah berbeda nyata berdasarkan Uji Jarak Berganda Duncan pada taraf 5\% (huruf kecil) dan 1\% (huruf besar)

\section{Gabah Kering Panen}

Pada Tabel 4 dapat dilihat bahwa faktor jumlah populasi berpengaruh nyata terhadap bobot gabah kering panen per plot. Rataan tertinggi terdapat pada perlakuan L1, sedangkan rataan terendah terdapat pada perlakuan L4. Hal ini menunjukkan bahwa sistem tanam mempengaruhi kemampuan tanaman padi dalam produksi, dimana sistem jajar legowo menghasilkan produksi tertinggi dibandingkan sistem lainnya. Menurut literatur Prasetiyo (2002), bahwa jarak tanam yang tepat dapat memberikan hasil yang tinggi, karena terdapat pembagian zat-zat hara dan sinar matahari, jumlah anakan berada dalam keadaan yang paling menguntungkan, pembuahan dan masaknya merata, dapat mencegah kerebahan, mengurangi pertumbuhan gulma, dan serangan hama penyakit, pemakaian benih menjadi lebih efisien, jumlah malai per satuan luas adalah optimum dengan panjang malai yang merata.

Pada faktor jumlah bibit terhadap parameter bobot gabah kering panen dapat dilihat bahwa rataan tertinggi terdapat pada perlakuan B2 dan rataan terendah terdapat pada perlakuan B3. Hal ini menunjukkan perlakuan 2 bibit, pertumbuhan selalu paling setinggi sehingga produksi yang dihasilkan juga tinggi. Hal ini berkaitan dengan unsur hara, jumlah cahayayang dapat diserap oleh tanaman, serta perkembangan tanaman.

Pada interaksi jumlah populasi tanaman dan jumlah bibit terhadap parameter bobot gabah kering panen, rataan tertinggi terdapat pada perlakuan B2L1 (jumlah 2 bibit dan jumlah populasi 60 tanaman per plot), sedangkan rataan terendah terdapat pada perlakuan B3L4 (jumlah 3 bibit dan jumlah populasi 190 tanaman). Hal ini menandakan bahwa dengan jumlah bibit yang banyak serta jumlah populasi yang semakin meningkat menyebabkan produksi tanaman tidak naik. Menurut literatur Satria (2017), bahwa aplikasi berbagai jarak tanam yang digunakan akan mempengaruhi produksi secara langsung. Proses ini dapat saja terjadi karena masih banyak faktor lingkungan lain yang mempengaruhi pertumbuhan dan perkembangan tanaman antaranya curah hujan, hama yang menyerang, anakan yang mati atau tidak produktif. 
Tabel 4. Pengaruh Jumlah Bibit dan Populasi Tanaman terhadap Bobot Gabah Kering Panen per Plot (g)

\begin{tabular}{|c|c|c|c|c|c|c|}
\hline \multirow{2}{*}{$\begin{array}{c}\text { Jumlah } \\
\text { Bibit }\end{array}$} & \multicolumn{5}{|c|}{ Populasi Tanaman } & \multirow{2}{*}{ Rataan } \\
\hline & L0 & L1 & L2 & L3 & L4 & \\
\hline \multicolumn{7}{|c|}{ 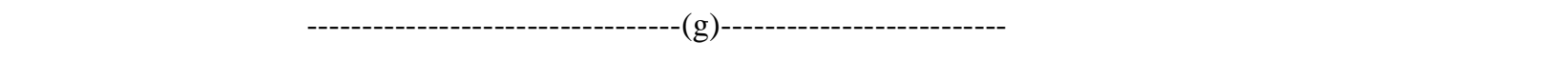 } \\
\hline B1 & $2633,33 \mathbf{b c d} \mathbf{A B}$ & $2545 \mathrm{cdABC}$ & 2700abcdAB & $2550 \mathbf{c d A B C}$ & 2741,33abcdAB & 2633,93abA \\
\hline B2 & $2796,67 \mathbf{a b c A B}$ & $2966,33 \mathbf{a A}$ & 2613,33 bcdAB & 2736,67 abcdAB & 2656,67abcdAB & $2753,93 \mathbf{a A}$ \\
\hline B3 & $2788,33 \mathbf{a b c A B}$ & $2959,33 \mathbf{a b A}$ & 2560cdABC & 2400deBC & $2093,33 \mathbf{e C}$ & $2560,2 \mathbf{b A}$ \\
\hline Rataan & $2739,44 \mathbf{a b A B}$ & $2823,56 \mathbf{a A}$ & $2624,44 \mathbf{b c A B}$ & $2562,22 \mathbf{b c B}$ & $2497,11 \mathbf{c B}$ & \\
\hline
\end{tabular}

Keterangan : Angka yang diikuti oleh huruf yang berbeda pada kolom yang sama adalah berbeda nyata berdasarkan Uji Jarak Berganda Duncan pada taraf 5\% (huruf kecil) dan 1\% (huruf besar)

\section{Gabah Kering Giling}

Tabel 5 menunjukkan bahwa faktor jumlah bibit berpengaruh nyata terhadap parameter bobot gabah kering giling per plot. Rataan tertinggi terdapat pada perlakuan L1, sedangkan rataan terendah terdapat pada perlakuan L4. Menurut literatur Abdulrachman dkk., (2013), menyatakan bahwa pada umumnya, varietas padi pada kondisi jarak tanam sempit akan mengalami penurunan kualitas pertumbuhan, seperti jumlah anakan dan malai yang lebih sedikit, panjang malai yang lebih pendek, dan tentunya jumlah gabah per malai berkurang jika dibandingkan pada kondisi jarak tanam lebar. Fakta di lapang membuktikan bahwa penampilan individu tanaman padi pada jarak tanam lebar lebih bagus jika dibandingkan dengan jarak tanam yang rapat.

Pada faktor jumlah bibit terhadap parameter bobot gabah kering giling dapat dilihat bahwa rataan tertinggi terdapat pada perlakuan B2 (jumlah 2 bibit) dan rataan terendah terdapat pada perlakuan B3 (jumlah 3 bibit). Hal ini menunjukkan bahwa perlakuan 2 bibit mengalami pertumbuhan yang paling tinggi karena persaingan yang terjadi antar tanaman dapat dikurangi. Hal ini berkaitan dengan unsur hara, jumlah cahaya yang dapat diserap oleh tanaman, serta perkembangan tanaman. Menurut literatur
Uphoff (2001), menyatakan bahwa apabila terjadi pemberian benih yang terlalu banyak dalam satu lubang tanam maka akan menimbulkan terjadinya persaingan unsur hara dan ruang gerak untuk perkembangan akar serta anakan akan semakin sempit sehingga akan mengakibatkan pertumbuhan terhambat serta produksinya rendah.

Pada interaksi jumlah populasi tanaman dan jumlah bibit terhadap parameter bobot gabah kering panen, rataan tertinggi terdapat pada perlakuan B2L1 (jumlah 2 bibit dan jumlah populasi 60 tanaman per plot), sedangkan rataan terendah terdapat pada perlakuan B3L4 (jumlah 3 bibit dan jumlah populasi 190 tanaman). Hal ini menandakan bahwa dengan jumlah bibit yang banyak serta jumlah populasi yang semakin meningkat menyebabkan produksi tanaman tidak naik. Menurut literatur Satria (2017), bahwa aplikasi berbagai jarak tanam yang digunakan akan mempengaruhi produksi secara langsung. Proses ini dapat saja terjadi karena masih banyak faktor lingkungan lain yang mempengaruhi pertumbuhan dan perkembangan tanaman antaranya curah hujan, hama yang menyerang, anakan yang mati atau tidak produktif. 
Tabel 5. Pengaruh Jumlah Bibit dan Populasi Tanaman terhadap Bobot Gabah Kering Giling per Plot (g)

\begin{tabular}{|c|c|c|c|c|c|c|}
\hline \multirow{2}{*}{$\begin{array}{c}\text { Jumlah } \\
\text { Bibit }\end{array}$} & \multicolumn{5}{|c|}{ Populasi Tanaman (L) } & \multirow[t]{2}{*}{ Rataan } \\
\hline & L0 & L1 & L2 & L3 & $\mathrm{L} 4$ & \\
\hline B1 & 2426,67bcdABCD & 2401,67cdeBCD & 2423,33abcdABCD & 2393,33bcdABCD & 2518abcdABC & 2432,6abA \\
\hline B2 & 2600abABC & $2783 \mathbf{a A}$ & 2413,33bcdABCD & 2480abcdABC & 2456,67bcdABCD & $2546,6 \mathbf{a A}$ \\
\hline B3 & 2655abcABC & $2693,33 \mathbf{a b} \mathbf{A B}$ & 2230bcdABCD & 2250deCD & $1983,33 \mathbf{e D}$ & $2362,33 \mathbf{b A}$ \\
\hline Rataan & $2560,56 \mathbf{a b A B}$ & $2626 \mathbf{a A}$ & $2355,56 \mathbf{c B}$ & $2374,44 \mathbf{c B}$ & $2319,33 \mathbf{c B}$ & \\
\hline
\end{tabular}

Keterangan: Angka yang diikuti oleh huruf yang berbeda pada kolom yang sama adalah berbeda nyata berdasarkan Uji Jarak Berganda Duncan pada taraf 5\% (huruf kecil) dan 1\% (huruf besar)

\section{SIMPULAN}

Penggunaan 2 bibit per lubang tanamnyata meningkatkan pertumbuhan dan produksi padi sawah (Oryza sativa L.). Semakin tinggi populasi tanaman maka nyata meningkatkan tinggi tanaman namun tidak nyata meningkatkan produksi tanaman akibat tingginya persaingan antar tanaman. Interaksi antara jumlah bibit per lubang tanam dan populasi tanamannyata mempengaruhi bobot gabah kering panen dan bobot gabah kering giling, tetapi tidak dengan parameter produksi lainnya.

\section{DAFTAR PUSTAKA}

Abdulrachman, S.,M. J. Mejaya, N. Agustiani, I. Gunawan, P. Sasmita,dan A. Guswara. 2013. Sistem Tanaman Legowo. Balai Pengkajian dan Pengembangan Pertanian.Di akses pada tanggal 26September 2018.

Ali, M., A. Hosir, dan Nurlina. 2017. Perbedaan Jumlah Bibit per Lubang Tanam Terhadap Pertumbuhan dan Hasil Tanaman Padi (Oryza sativa L.) dengan Menggunakan Metode The System Rice Intensification. Gontor Agrotech Science Journal Vol. 3 No. 1 Aribawa, I. B. 2012. Pengaruh Sistem Tanam Terhadap Peningkatan Produktivitas
Padi di Lahan Sawah Dataran Tinggi Beriklim Basah. Seminar Nasional: Kedaulatan Pangan dan Energi. Fakultas Pertanian Universitas Trunojoyo, Madura

Makarim, A.K. dan E. Suhartatik. 2009. Morfologi dan Fisiologi Tanaman Padi. Balai Besar Penelitian Tanaman Padi. Sukabumi. Subang hal 317.

Marlina, Setyono dan Y. Mulyaningsih. 2017. Pengaruh Umur Bibit dan Jumlah Bibit Terhadap Pertumbuhan danHasil Panen Padi Sawah (Oryza SativaL.) Varietas Ciherang. Jurnal Pertanian pISSN 2087-4936 e-ISSN 2550-0244 Volume 8 Nomor 1.

Nararya, M. B. A. , M. Santoso, A. Suryanto, 2017. Kajian Beberapa Macam Sistem Tanam dan Jumlah Bibit per Lubang Tanam pada Prduksi Tanaman Padi Sawah (Oryza sativa L.) Varietas Inpari 30. Jurnal Produksi Tanaman Vol.5 No.8 : 1338-1345

Prasetiyo, Y. T. 2002. Budidaya Padi Tanpa Olah Tanah. Kanisius. Yogyakarta.

Sembiring, H. 2001. Komoditas Unggulan Pertanian Provinsi Sumatera Utara. Sumatera Utara: Badan Penelitian dan Pengembangan Teknologi Pertanian. Sumatera Utara.

Simangunsong, E. R. A. , E. M. Harahap, A. Lubis. , 2018. Pengaruh Jumlah Bibit 
dan Modifikasi Sistem Tanam Jajar Legowo Terhadap Pertumbuhan dan Produksi Padi Sawah (Oryza sativa L.) Di Desa Tanjung Mulia Kecamatan Tanjung Morawa Kabupaten Deli Serdang. Jurnal Pertanian Tropik Vol.5. No.2. (39) 292- 300

Sumardi. 2010. Produktivitas Padi Sawah Pada Kepadatan Populasi Berbeda. Jurnal Ilmu-Ilmu Pertanian Indonesia. 12 (1): 49-54

Uphoff, N. , 2001. Oppurtinities for Raising Yields by Changing Management Practices : The System of Rice Intensification in Madagascar : Agroecological Innovation : Participatory Development.

Wangiana, W., L. Zaprildan Sanisah. 2009. Pertumbuhan dan Hasil Tanaman Padi Varietas Ciherang dengan Teknik Budidaya SRI Pada Berbagai Umur dan Jumlah Bibit per Lubang Tanam. Crop Agro, 2(1): 70-78 